\title{
Hydrogeochemistry of the Middle Benue Trough, Nigeria
}

\author{
Mohammed Suleiman Chaanda ${ }^{1,2}$, Ali Moumouni ${ }^{3}$ \\ ${ }^{1}$ Deparment of Earth Sciences, Federal University of Petroleum Resources, Effurun, Nigeria \\ ${ }^{2}$ School of Geography, Earth \& Environmental Sciences, University of Plymouth, Drake Circus, UK \\ ${ }^{3}$ Department of Geology, Faculty of Sciences and Technology, University Dan Dicklo Dankoulodo, Maradi, Niger Republic
}

Email address:

chaandamohammed@gmail.com (M. S. Chaanda), alimoumouni2005@yahoo.fr (A. Moumouni)

\section{To cite this article:}

Mohammed Suleiman Chaanda, Ali Moumouni. Hydrogeochemistry of the Middle Benue Trough, Nigeria. Journal of Water Resources and Ocean Science. Vol. 7, No. 5, 2018, pp. 70-76. doi: 10.11648/j.wros.20180705.11

Received: September 29, 2018; Accepted: November 16, 2018; Published: January 10, 2019

\begin{abstract}
There are many sources of underground water in the Middle Benue Trough, which have varying composition and constituents. Water samples from saline springs, boreholes, hand-dug wells and rivers / streams from the Middle Benue Trough are collected and analysed for cations, anions and heavy metals, using atomic absorption spectrometry (AAS); with aim of determining the concentration of the cations and anions in relation to their suitability within the tolerance limit. The analytical results revealed that the major cations such as Copper $(\mathrm{Cu})$, Sodium $(\mathrm{Na})$, Potassium (K), Iron (Fe) and Magnesium $(\mathrm{Mg})$ have their concentrations within World Health Organization (WHO) drinking water permissible limits. However, Lead ( $\mathrm{Pb}$ ), Arsenic (As), Selenium (Se), Zinc ( $\mathrm{Zn})$ and Manganese $(\mathrm{Mn})$ had concentration above the WHO standard and the Standard Organisation of Nigeria (SON) limits. These high values are mostly associated with the Baryte and Lead-Zinc mineralisation associated with either Keana or Awgu formations in the Middle Benue Trough and the saline brine origin of some few aquifers. This situation could potentially have a negative impact on the available water resources in the area with high risk for human consumption, although suitable for agricultural purposes. It is highly recommended that the water quality in this area is monitored from time to time and water borne diseases be systematically and promptly handled.
\end{abstract}

Keywords: Benue Trough, Nigeria, Groundwater, Hydrochemistry

\section{Introduction}

Geographical and Climatic Setting of the Study Area

The study area falls within Latitudes $8^{0} 25^{\prime} 43^{\prime \prime} \mathrm{N}$ and $8^{0} 20^{\prime} 40^{\prime \prime} \mathrm{N}$ on its northern and southern boundary, and Longitudes $8^{0} 48^{\prime} 8$ ' $\mathrm{E}$ and $8^{0} 55^{\prime} 55^{\prime \prime} \mathrm{E}$ on its eastern and western boundaries (Figure 1).

Climatologically the area enjoys the spatial and temporal distribution of the climatic elements. Temperatures are generally high partly because of its location in the tropical sub-humid climatic belt. There is gradual increase in temperature from January to March. The onset of rainfall in April ushers in a noticeable decline in temperature. This was made possible by the blanket effect of cloud cover over the region. Relative humidity rises from February to a maximum of about $88 \%$ in July. Steady rains commence in April when the relative humidity will reach about $75 \%$. The variation in rainfall has significant effect on the underground water accumulation, yield, recharge and even economic activities particularly rain-fed agriculture. Rainfall occurrences are between April and October yearly while November to March is characterised by dryness. The average rainfall value during rainy season ranges from $1100 \mathrm{~mm}$ to about $2000 \mathrm{~mm}$ [1-2].

The vegetation falls within the southern guinea savannah zone between the wet high forest zone of the south and the dry savannah zone of the north. The clearing of the vegetation for farming, fuel wood extraction for domestic and cottage industrial uses and saw milling has led to the development of regrowth vegetation at various levels of several developments.

Brief Geology of the Middle - Benue Trough

The geological mapping of the Middle Benue Trough was undertaken [3], where six major lithostratigrahic units were identified and that work constitutes until now the reference document in the study area. The Benue Trough is a rift basin in central West Africa that extends NNE - SSW for about $800 \mathrm{~km}$ in length and $150 \mathrm{~km}$ in width (Figure 1). 


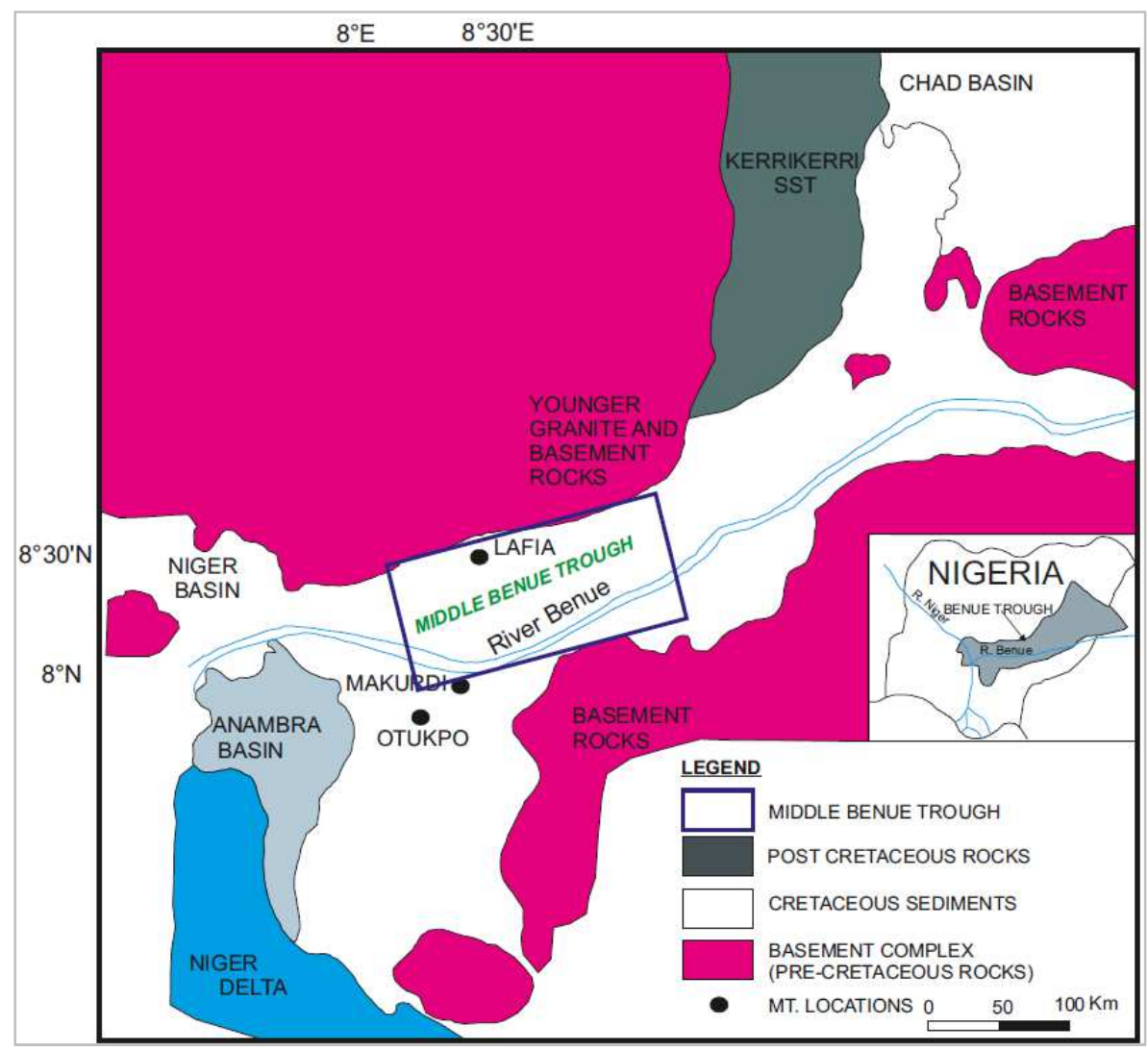

Figure 1. Geological Map of the Benue Trough and the Surrounding areas showing an insert of the Middle Benue Trough.

The Benue Trough originated in the latest Jurassic? to Early Cretaceous when lithospheric stretching resulted in the simultaneous initiation of the various structural elements making up the West and Central African Rift System [4]. It contains up to $6000 \mathrm{~m}$ of Cretaceous - Tertiary sediments of which those predating the mid - Santonian have been compressionally deformed, faulted, and uplifted in several places. Compressional Folding during the mid - Santonian episode affected the whole Benue Trough and quite intense, producing over 100 anticlines and synclines [5]. Stratigraphic description of the trough has been presented by [5-7].

The origin and tectonic history of the Benue Trough is associated with the break - up of the continents of Africa and South America [break - up of Gondwanaland]. This break up was followed by the drifting apart of these continents, the opening of the South Atlantic, and the growth of the mid Atlantic ridges $[5,8]$. The geology of the Benue Trough as it relates to its origin and tectonic evolution has been widely discussed and reviewed by the following [3, 7, 9-11].

Stratigraphy of the middle Benue trough

According to [3, 12], there are six litho-stratigraphic successions identified in the middle Benue Trough, these are:

1. Asu River Group (Albian Arufu, Uomba, Gboko formations)

2. Awe Formation (Late Albian - Early Cenomanian)

3. Ezeaku Formation (Late Cenomanian)

\section{Awgu Formation}

5. Lafia Formation Asu River Group (Arufu-Uomba-Gboko)

The Asu River Group is the oldest marine deposit in Nigeria. The Asu River Group is deposited during the MidAlbian marine transgression of the South Atlantic-Gulf of Guinea. The lithologic composition of this group/ formation comprises mainly limestones, shales and calcareous shales, micaceous siltstones, mudstones and clays. In middle Benue Trough, the Asu River Group crops out mainly in the anticline east of Keana town and south of Azara. This formation is very fossiliferous. Ammonites and foraminifera (mainly agglutinated forms) occur abundantly in the formation [7].

\section{Awe Formation}

The Awe Formation is regarded as passage (i.e. transition) beds during the Late Albian Early Cenomanian Regression $[3,8]$. This formation overlies the Asu River Group. The type locality is in the town of Awe where the thickness is about $100 \mathrm{~m}$ (Figure 2). The formation consists of flaggy, whitish, and medium to coarse-grained calcareous sandstones, carbonaceous shales and claystone's. The sandstones become fine-grained and more micaceous towards the base with fine current beddings. The Awe Formation is generally not fossiliferous. However, a few gastropods and pelicypods occur in the formation. 


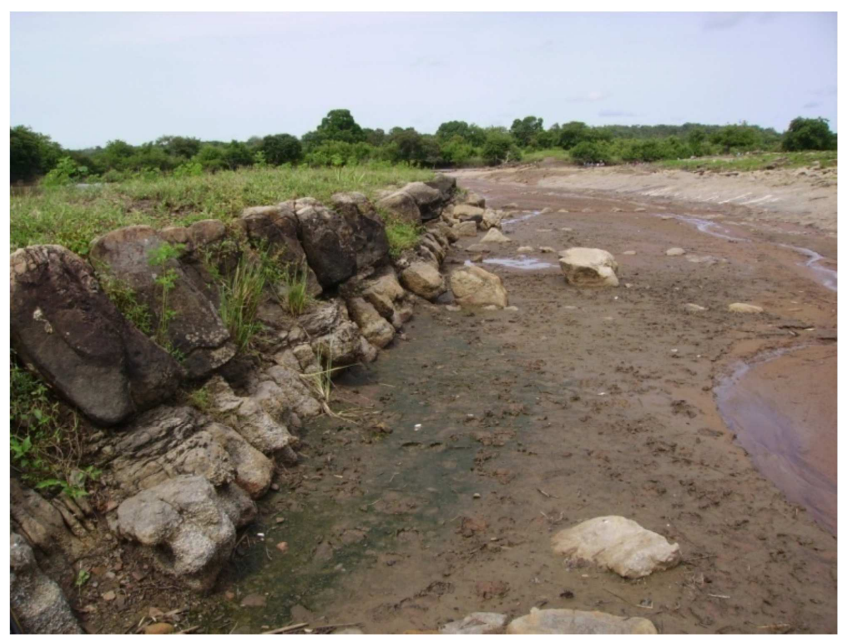

Figure 2. Outcrop of Awe Formation. Here sandstone beds intercalated with Shale \& siltstone indicating Transgressive/Regressive deposits in Awe area.

\section{Keana Formation}

The Keana Formation (Figure $3 \& 4$ ) resulted from the Cenomanian regression, which deposited fluviodeltaic sediments. In the Lafia-Awe area, the Keana Formation can be located southwards into the Makurdi Formation and it is believe to be its lateral equivalent. This formation consists mainly of cross-bedded, coarse-grained feldspathic sandstones. The sandstones are poorly sorted, and occasionally contains conglomerates and bands of shales and Limestone's towards the top. The Keana Formation flanks both sides of the Keana anticline. Massive, outcrops (Figures 4) occur at many locations as recorded in the studied sections. Example are Keana, Azara and Daudo. The Keana Formation generally is not fossiliferous. Many reviews on this area were reported [7].

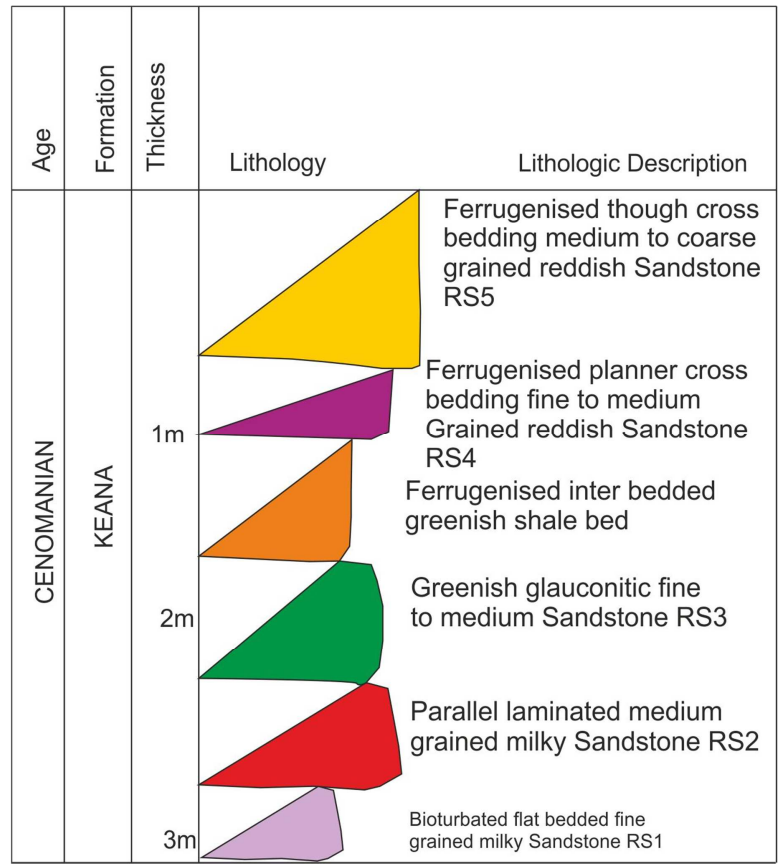

Figure 3. A section of Keana Formation at River Okpalaga, Keana.

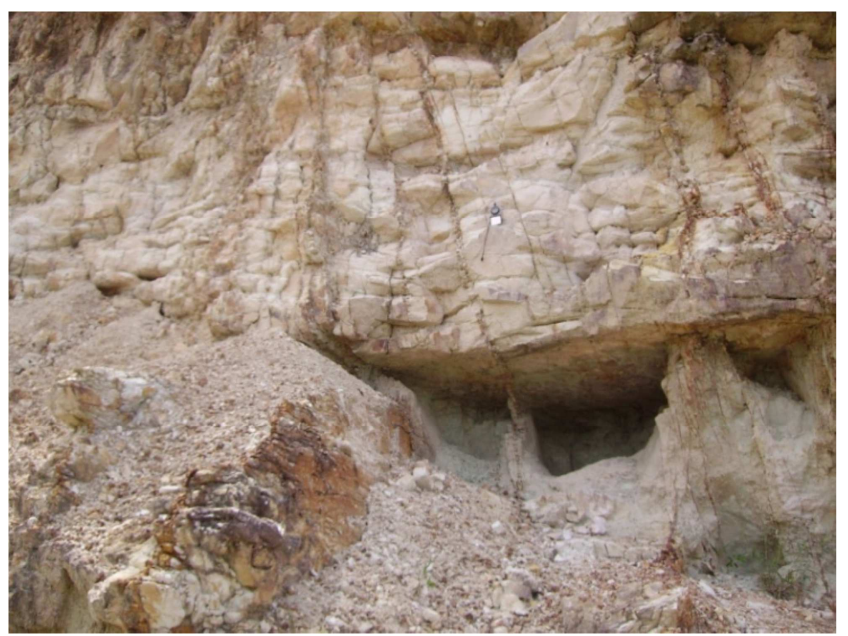

Figure 4. Highly fracture Sandstone/intercalated with mudstone intruded by Hydrothermal veins of Baryte of Keana Formation.

\section{Awgu Formation}

The Awgu Formation conformably overlies the Ezeaku Formation. The Awgu Formation was desposited in a generally shallow sea during a third transgression presumed to have begun in the latest Turonian, peaked during the early Coniacian and terminated in early Santonian. The type locality as described by [8] lies between the town of Awgu and Ndeaboh in Anambra State. The deposition of the Awgu Formation marks the end of marine sedimentation in this part of the Benue Trough. The formation is composed of bluishgray to dark-black carbonaceous shales, calcareous shales, shaley limestone, limestones sandstones, siltstones, and coal seams (Figure 5).

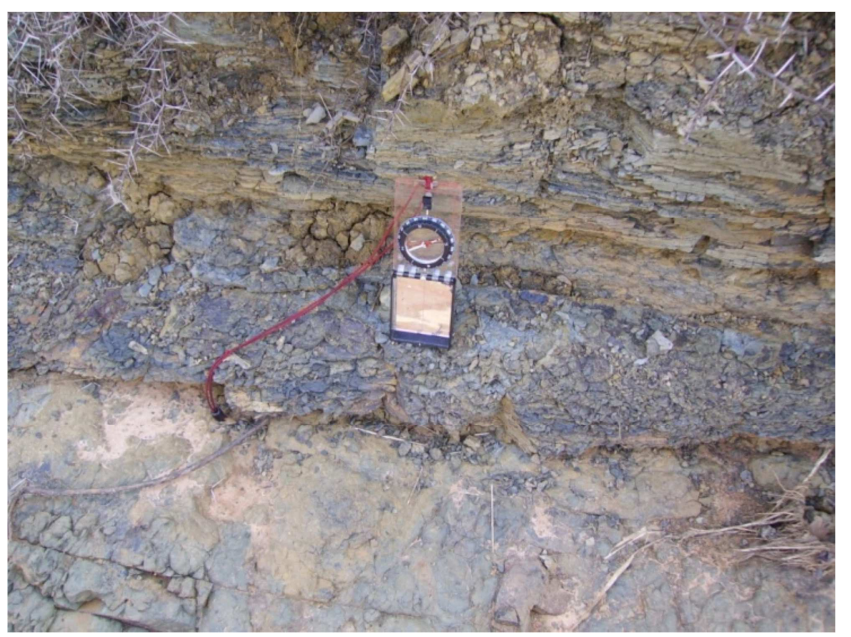

Figure 5. A section of Awgu Formation depicting bluish-gray to dark-black carbonaceous shales along Keana - Awe road.

\section{Aim and Objectives of the paper}

This paper is aim at assessing the quality of groundwater from different sources such as saline springs, boreholes, pounds, streams and hand dug wells. The study is to determine the physico-chemical parameters of water and to compare them with the permissible limits of the World Health Organization drinking water and Standard 
Organisation of Nigeria (SON) standard.

\section{Material and Methods}

Sampling was jointly performed with staff of the department of Hydrogeology Nigeria Hydrogeological Services Agency (NIHSA). More than ten saline springs at Keana, Ribi, Awe Tsohon Gari and Akiri were recorded and twenty (20) water samples collected (Table 1 and Figure 6). At the time of sampling in the field, basic physico-chemical parameters such as temperature, $\mathrm{pH}$ and electrical conductivity were determined in-situ using portable standard digital equipment (Hatch Meter). The waters were poured into $100 \mathrm{ml}$ HDPE polythene bottles from the sources. A separate sample for nutrient analyses was collected and treated for chloroform. The bottles were rinsed three times, and then filled to prevent degassing. Water samples were filtered through a $0.45 \mu \mathrm{m}$ membrane and kept under refrigerated condition prior to their shipment to the laboratory.

While in the laboratory, water samples were analysed for major cations and anions and for nutrient content. For quality control, ironic error balance was determined by calculation, where the error balance did not exceed $5 \%$.

The analyses was performed at the Geochemical Laboratory, Department of Geology, University of Jos using a Dionex DX-120 ironic chromatograph for anions and a Perkin Elmer 300 Atomic Absorption Spectrometer (AAS) for cations.

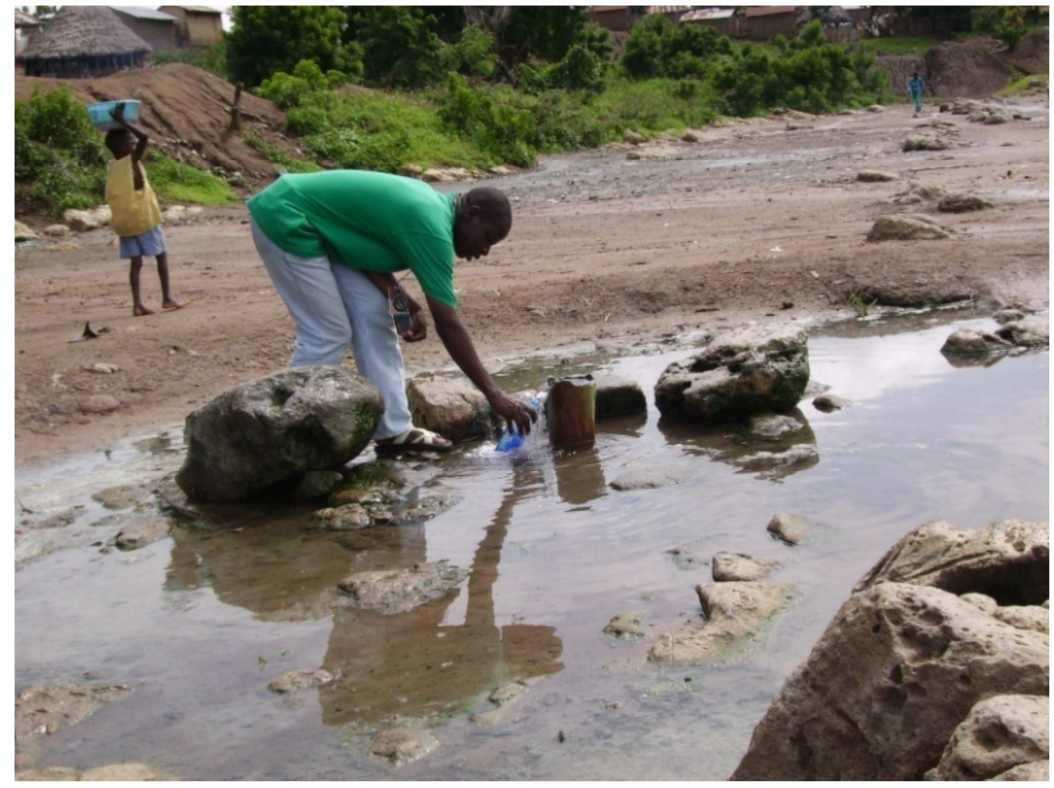

Figure 6. Water sampling at one of the Saline Springs at Tsohon Gari, Awe by the first author.

Table 1. Water sampling locations with corresponding physical parameters (in-situ).

\begin{tabular}{|c|c|c|c|c|c|c|c|}
\hline $\mathbf{S} / \mathbf{N}$ & Name & pH & Tempt $\left({ }^{\circ} \mathrm{C}\right)$ & Latitude $\mathbf{N}\left({ }^{0}\right.$ “" $)$ & Longitude E ( $\left.{ }^{0}{ }^{\prime \prime}\right)$ & Altitude (Ft) & Remark \\
\hline 1 & G. S. S Lafia & 5.46 & 30.5 & $8^{\circ} 30.01$ & $8^{\circ} 30.91^{\prime}$ & 700 & Borehole \\
\hline 2 & Nasarawa Estate & 6.80 & 29.8 & $8^{\circ} 28.79^{\prime}$ & $8^{\circ} 32.81^{\prime}$ & 500 & Hand-dug Well \\
\hline 3 & Agwantashi 1 & 7.20 & 29.1 & $8^{\circ} 19.25^{\prime}$ & $8^{\circ} 50.99^{\prime}$ & 600 & Borehole \\
\hline 4 & Agwatashi 2 & 7.70 & 32.7 & $8^{\circ} 19.91^{\prime}$ & $8^{\circ} 51.01^{\prime}$ & 600 & Borehole \\
\hline 5 & Adudu & 8.20 & 30.6 & $8^{\circ} 17.57^{\prime}$ & $9^{\circ} 00.35^{\prime}$ & - & Hand-dug Well \\
\hline 6 & Awe Police Station & 7.20 & 32.0 & $8^{\circ} 06.35^{\prime}$ & $9^{\circ} 00.51^{\prime}$ & - & Borehole Taste salty \\
\hline 8 & Keana & 7.5 & 31.0 & $8^{\circ} 08.93^{\prime}$ & $8^{\circ} 17.78^{\prime}$ & 400 & Borehole \\
\hline 9 & Obi Agada & 7.20 & 31.7 & $8^{\circ} 22.02^{\prime}$ & $8^{\circ} 16.20^{\prime}$ & 600 & Hand-dug Well \\
\hline 10 & Ope Obi & 6.40 & 30.5 & $8^{\circ} 22.13^{\prime}$ & $8^{\circ} 16.15^{\prime}$ & 600 & \\
\hline 11 & Sabon Gida & 8.00 & 33.0 & $8^{\circ} 37.96^{\prime}$ & $8^{\circ} 57.11^{\prime}$ & 400 & Borehole \\
\hline 12 & DEP Project & 5.40 & 29.7 & $8^{\circ} 37.47^{\prime}$ & $8^{\circ} 56.21^{\prime}$ & 500 & Hand-dug Well \\
\hline 13 & Asakio PHC & 6.20 & 32.1 & $8^{\circ} 35.18^{\prime}$ & $8^{\circ} 58.31^{\prime}$ & 500 & Borehole \\
\hline 14 & Gidan Mai Akuya & 5.40 & 31.7 & $8^{\circ} 32.73^{\prime}$ & $8^{\circ} 11.21^{\prime}$ & 600 & Hand-dug Well \\
\hline 16 & Lamba & 5.50 & 33.7 & $8^{\circ} 23.61^{\prime}$ & $8^{\circ} 21.51^{\prime}$ & - & Hand-dug Well \\
\hline 17 & Tudun Angba & 4.50 & 31.8 & $8^{\circ} 34.49^{\prime}$ & $8^{\circ} 38.86^{\prime}$ & 600 & Borehole \\
\hline 18 & Shabu & 5.40 & 31.8 & $8^{\circ} 34.49^{\prime}$ & $8^{\circ} 33.11^{\prime}$ & 500 & Hand-dug Well \\
\hline 19 & Coll. Of Agric, Lafia & 6.10 & 33.7 & $8^{\circ} 33.27^{\prime}$ & $8^{\circ} 32.76^{\prime}$ & & Borehole \\
\hline 20 & Savannah Hotel Lafia & 5.30 & 32.7 & $8^{\circ} 31.17^{\prime}$ & $8^{\circ} 031.20^{\prime}$ & 600 & Borehole \\
\hline
\end{tabular}




\section{Results}

The results obtained are as shown in tables 2 and 3 below.

Table 2. Physico-chemical parameters of water samples from the Middle Benue Trough.

\begin{tabular}{|c|c|c|c|c|c|c|c|}
\hline S/No & Parameter/Sample ID & SW004 & RW008 & W002 & W001 & RS07 & SW006 \\
\hline 1 & $\mathrm{pH}$ & 7.80 & 7.33 & 6.44 & 6.21 & 7.83 & 7.26 \\
\hline 2 & Phosphate (mg/l) & 0.004 & 0.000 & 0.007 & 0.009 & 0.000 & 0.000 \\
\hline 3 & Chloride & 6.74 & 4.69 & 7.88 & 5.34 & 6.67 & 5.009 \\
\hline 4 & Nitrate & 0.0 & 0.0 & 0.0 & 0.0 & 0.0 & 0.0 \\
\hline 5 & Bicarbonates (mg/l) & 14.53 & 9.66 & 12.11 & 12.1 & 10.93 & 11.33 \\
\hline 6 & Turbidity & 1.96 & 3.42 & 9.53 & 37.90 & 0.92 & 1.73 \\
\hline 7 & Conductivity (m/s) & 0.99 & 0.28 & 0.12 & 0.70 & 0.94 & 0.80 \\
\hline 8 & Alkalinity & 1.27 & 1.21 & 0.94 & 1.14 & 0.88 & 1.89 \\
\hline 9 & TDS (mg/l) & 781 & 810 & 902 & 1420 & 899 & 508 \\
\hline 10 & BOD & 7.58 & 7.55 & 4.34 & 6.53 & 6.59 & 8.99 \\
\hline 11 & Total Hardness & 3.42 & 5.99 & 7.22 & 8.56 & 4.94 & 3.66 \\
\hline 12 & $\% \mathrm{DO} 2$ & 59 & 88 & 57 & 77 & 78 & 69 \\
\hline
\end{tabular}

Table 3. Chemical analysis of Water Samples in $\left(\mathrm{mg} / \mathrm{dm}^{3}\right)$ [Preliminary results] in the Middle Benue Trough (Units are in Mg/l).

\begin{tabular}{|c|c|c|c|c|c|c|c|c|c|c|c|c|c|c|c|}
\hline S/No & Sample ID & $\mathbf{N a}$ & $\mathbf{K}$ & $\mathbf{N i}$ & $\mathrm{Cu}$ & Mg & $\mathrm{Fe}$ & $\mathbf{C a}$ & Zn & $\mathbf{P b}$ & Cd & As & $\mathrm{Se}$ & $\mathrm{Cr}$ & Mn \\
\hline 1 & SW004 & 3.24 & 2.71 & 0.05 & 0.12 & 5.44 & 1.89 & 16.88 & 0.22 & 0.02 & 0.00 & 0.32 & 0.04 & 0.40 & 0.07 \\
\hline 2 & RW008 & 3.49 & 2.24 & 0.07 & 0.31 & 7.77 & 2.66 & 10.89 & 0.44 & 0.06 & 0.00 & 0.09 & 0.20 & 0.19 & 0.19 \\
\hline 4 & W001 & 3.56 & 1.95 & 0.09 & 0.21 & 12.91 & 1.66 & 13.93 & 0.30 & 0.02 & 0.00 & 0.03 & 0.07 & 0.55 & 0.19 \\
\hline 5 & RS07 & 2.11 & 2.00 & 0.18 & 0.40 & 9.98 & 2.51 & 5.95 & 0.21 & 0.02 & 0.00 & 0.03 & 0.45 & 0.23 & 0.50 \\
\hline \multirow[t]{2}{*}{6} & SW006 & 2.98 & 1.01 & 0.02 & 0.26 & 9.13 & 0.79 & 13.01 & 0.31 & 0.17 & 0.00 & 0.31 & 0.21 & 0.01 & 0.22 \\
\hline & NIS Standard & 200 & & 0.02 & 1 & 0.20 & 0.3 & & 3.0 & 0.01 & 0.003 & 0.01 & & 0.05 & 0.2 \\
\hline
\end{tabular}

\section{Physical Parameters}

The $\mathrm{pH}$ measurements of groundwater samples in the study area are slightly acidic and ranges from 4.50 to 8.20 with average mean of 7.15 . The water samples have a $\mathrm{pH}$ within the guidelines range of 6.5 to 8.5 . Groundwater temperature varies between $29.1{ }^{0} \mathrm{C}$ to $41.2{ }^{0} \mathrm{C}$ with a mean of $33.0{ }^{0} \mathrm{C}$. Specific electric conductivity values of $0.0 .12 \mathrm{~m} / \mathrm{s}$ to as high as $0.99 \mathrm{~m} / \mathrm{s}$. Average is $0.70 \mathrm{~m} / \mathrm{s}$. The corresponding values of total dissolved solids (TDS) measured in-situ range from $781 \mathrm{mg} / 1$ to $1420 \mathrm{mg} / 1$ with a mean of $550 \mathrm{mg} / 1$ (Tables 2 \& 3).

\section{Major Cations}

The major cations that are present in the water samples from the area of study include sodium, potassium, calcium, magnesium, copper, zinc and iron. Sodium $(\mathrm{Na}+)$ has concentrations that range from $1.8 \mathrm{mg} / 1$ to $3.56 \mathrm{mg} / 1$ and mean of $2.88 \mathrm{mg} / \mathrm{l}$. This falls within the permissible limit $(<50 \mathrm{mg} / \mathrm{l})$ of the Standard Organization of Nigeria (SON) and the WHO [18, 20-21]. Potassium $\left(\mathrm{K}^{+}\right)$has concentrations varying from $1.01 \mathrm{mg} / \mathrm{l}$ to $2.97 \mathrm{mg} / \mathrm{l}$ with a mean of 12.03 $\mathrm{mg} / \mathrm{l}$. Calcium $\left(\mathrm{Ca}^{2+}\right)$ concentrations range from $5.95 \mathrm{mg} / \mathrm{l}$ to $16.88 \mathrm{mg} / \mathrm{l}$ with mean value of $58.22 \mathrm{mg} / \mathrm{l}$, which is within the permissible limit. Magnesium $\left(\mathrm{Mg}^{2+}\right)$ concentrations range from $5.44 \mathrm{mg} / \mathrm{l}$ to $12.98 \mathrm{mg} / \mathrm{l}$ with a mean of 46.57 $\mathrm{mg} / \mathrm{l}$. Copper $(\mathrm{Cu})$ has concentrations range from $0.10-0.40$ $\mathrm{mg} / \mathrm{l}$ with an average of $0.23 \mathrm{mg} / \mathrm{l}$ which is within the permissible limit. Zinc ( $\mathrm{Zn}$ ) occurs in concentrations ranging from $0.21-0.53 \mathrm{mg} / \mathrm{l}$ with an average of $0.34 \mathrm{mg} / \mathrm{l}$, which is above permissible limit. Iron $\left(\mathrm{Fe}^{2+}\right)$ occurs in concentration ranges from 0.79 to 2.66 with an average of $1.96 \mathrm{mg} / \mathrm{l}$, which are within permissible limit that is suitable for drinking

For the major anions, Nitrate $\left(\mathrm{NO}_{3}\right)$ concentration was nil. Phosphate $\left(\mathrm{PO}_{4}\right)$ concentrations range from $0.00 \mathrm{mg} / \mathrm{l}$ to $0.009 \mathrm{mg} / \mathrm{l}$ with an average of $0.007 \mathrm{mg} / \mathrm{l}$ within the permissible limit and suitable for drinking. Sulphate occurs with concentrations within the permissible limit (Table 4).

Heavy Metals

Cadmium (Cd) was not detected at any concentration level. Nickel (Ni) has concentrations ranging from $0.02 \mathrm{mg} / 1$ to $0.19 \mathrm{mg} / \mathrm{l}$ with an average of $0.1 \mathrm{mg} / \mathrm{l}$ which is within the permissible limit of $0.07 \mathrm{mg} / 1$ or $70 \mu \mathrm{g} / \mathrm{l}$ of (WHO) but above the (SON) maximum permissible limit [18, 20-21]. The concentrations of Lead $(\mathrm{Pb})$ range from $0.01 \mathrm{mg} / 1$ to 0.06 $\mathrm{mg} / \mathrm{l}$ with mean of $0.05 \mathrm{mg} / \mathrm{l}$, which is above WHO standard of $0.002 \mathrm{mg} / \mathrm{l}$ [20-21]. The concentrations of Manganese $(\mathrm{Mn})$ range from $0.07 \mathrm{mg} / 1$ to $0.50 \mathrm{mg} / \mathrm{l}$ with mean of 0.233 $\mathrm{mg} / \mathrm{l}$, which is also above the permissible limit for Drinking Water (Table 3 and 4). 
Table 4. Range of concentration of various major and Traced elements in Water Samples in (mg/dm ${ }^{3}$ ) [Preliminary results] in the Middle Benue Trough (Units are in $\mathrm{Mg} / \mathrm{ll}$ and their comparison with WHO 2011 and NIS 2007.

\begin{tabular}{|c|c|c|c|c|c|}
\hline \multirow[b]{2}{*}{ Constituents } & \multicolumn{2}{|l|}{ WHO 2011} & \multicolumn{2}{|l|}{ NIS 2007} & \multirow{2}{*}{$\begin{array}{l}\text { Mean } \\
\text { Values in } \\
\text { Study Area }\end{array}$} \\
\hline & Highest Desirable Level & $\begin{array}{l}\text { Maximum } \\
\text { Permissible Limit }\end{array}$ & $\begin{array}{l}\text { Highest Desirable } \\
\text { Level }\end{array}$ & $\begin{array}{l}\text { Maximum } \\
\text { Permissible Limit }\end{array}$ & \\
\hline $\mathrm{pH}$ & $7-8.5$ & $6.5-9.2$ & & $6.5-8.5$ & 7.15 \\
\hline Total Hardness & $\begin{array}{l}\text { Not a health concern at levels } \\
\text { found in drinking water }\end{array}$ & & & 150 & \\
\hline TDS (mg/l) & 100 & 500 & & 500 & 550 \\
\hline Electrical conductivity $(\mathrm{m} / \mathrm{s})$ & & & & 1000 & 0.70 \\
\hline Temperature $\left({ }^{\circ} \mathrm{C}\right)$ & & & & Ambient & 33.0 \\
\hline Calcium & & & & & 58.22 \\
\hline Magnesium & & & & 0.20 & 46.57 \\
\hline Sodium & & & & 200 & 2.88 \\
\hline Potassium & No health concern & & & & 12.03 \\
\hline Chloride & & & & 250 & \\
\hline Cyanide & & & & 0.01 & \\
\hline Fluoride & 1.5 & 10 & & 1.5 & \\
\hline Nitrate & 3 & 50 & & 0.2 & Nil \\
\hline Phosphate & & & & & 0.007 \\
\hline Copper & 2.0 & 3.0 & & 1 & 0.23 \\
\hline Iron & No health concern & & & 0.3 & 1.96 \\
\hline Lead & & 0.01 & & 0.01 & 0.05 \\
\hline Manganese & & & & 0.2 & 0.233 \\
\hline Cadmium & & & & 0.003 & Nil \\
\hline Nickle & 0.02 & 0.07 & & 0.02 & 0.1 \\
\hline Cobalt & & & & & \\
\hline Chromium & & 0.05 & & & \\
\hline Zinc & & & & 3 & 0.34 \\
\hline Selenium & & 0.04 & & & \\
\hline Aluminum & & & & 0.2 & \\
\hline Mercury & & 0.006 & & 0.001 & \\
\hline Arsenic & & & & 0.01 & \\
\hline
\end{tabular}

\section{Discussion}

Water is one of the most important resources that sustains human life. The importance depends on many parameters, such as the quality for the intended use, which in turn depends on the geological environment, natural movement of fluid, recovery and utilization [13]. The availability and access to fresh water is a critical issue all over the world. Groundwater constitutes the only reliable water supply for drinking and irrigation purposes [14]. Hence understanding the groundwater quality changes, solute transport mechanism and identifying recharge areas in the groundwater zone has become important in protecting human health. This is because groundwater contains a wide variety of dissolved inorganic species in various concentrations because of the biochemical interactions between the water and geological materials through which it flows and to a lesser extent because of contributions from the atmosphere, surface water bodies and anthropogenic activities [15-7].

Considering the concentration of Nickel in samples SW001, RW008, W001 and SW006 (representing stream water, river water and saline water respectively) the amount of Nickel is above the permissible limit of the SON [18]. Nickel and Arsenic are associated with carcinogenic, and has the risk of exposing the inhabitant of the study area to cancer related diseases [19].

Zinc on the other hand has average concentration above both SON and WHO permissible limits [18, 20-21]. It is one of the common cause of cancer and has the risk of interference with vitamin D metabolism, which can easily affect the mental development in infants, and is toxic to the central and peripheral nervous systems [18].

Manganese mean value of $0.233 \mathrm{mg} / \mathrm{l}$, is recorded from the analysis and this value is above the permissible limit. Excess of manganese in the human body system can lead to Neurological disorder. As time goes on, it will affect the health delivery system and subsequently will reflect on the GDP of the country.

Mean value of lead concentration of $0.05 \mathrm{mg} / \mathrm{l}$ is also higher than permissible limit. This is observed in samples RW008 and RS07. The area is characterised by baryte and Lead-Zinc mineralization. Previous studies showed that the area is experiencing potential danger of the release of $\mathrm{Pb}$ associated toxic elements ( $\mathrm{As}, \mathrm{Cd}, \mathrm{Sb}$ etc.) into the water system [21]. Moreover, trace elements study in the same area has indicated that $\mathrm{Pb}, \mathrm{As}, \mathrm{Cd}, \mathrm{Sb}$ etc., are released into water bodies, rendering such waters unsafe for human consumption [23]. Most common symptoms of lead poisoning are symptoms to anemia, severe intestinal pain, paralysis of nerves and to some extent loss of appetite and fatigue in adults [24]. It can also lead to irreversible mental damage in children.

The presence of selenium as well as arsenic, cadmium and mercury in water endangers its use. Selenium was detected in almost all the samples analyzed for heavy metals. Health problems related to it include decay in hair, nail and teeth and 
neurological and skin disorder [25]. The presence of persons with brown teeth in the study area were observed but not very common and this might be an indication of excess selenium or fluoride in the waters and caution needs to be taken when using the waters, preferably it must be treated, and the quality checked on regular basis.

\section{Conclusion}

Chemical analysis of water from spring, streams and boreholes in the study area reveals concentrations of lead, arsenic, selenium, nickel and manganese are above the WHO Drinking Water Standards. This situation is cause by the geology of area specifically the occurrence of barite and lead/zinc mineralisations in the study area. The use of such water for drinking mostly for long-term consumption may have serious health problems, there is for adequate treatment of the water regularly. However, the water can be put to use for both Industrial and Irrigation purposes with minimal concern.

\section{References}

[1] Odjugo, P. A. (2005). An analysis of rainfall patterns in Nigeria. Global Journal of Environmental Sciences, 4(2), 139-145.

[2] Yusuf, N., Okoh, D., Musa, I., Adedoja, S., and Said, R. (2017). A Study of the Surface Air Temperature Variations in Nigeria. The Open Atmospheric Science Journal, 11(1).

[3] Offodile, M. (1975). A review of the geology of the Benue Trough, Nigeria [J]. Journal African Earth Sciences, 3, 283-291.

[4] Fairhead, J. D. (1986). Geophysical controls on sedimentation within the African rift systems. Geological Society, London, Special Publications, 25(1), 19-27.

[5] Benkhelil, J. (1989). The origin and evolution of the Cretaceous Benue Trough (Nigeria). Journal of African Earth Sciences (and the Middle East), 8(2), 251-282. doi:https://doi.org/10.1016/S0899-5362(89)80028-4.

[6] Benkhelil, J., Dainelli, P., Ponsard, J. F., Popoff, M., and Saugy, L. (1988). The Benue Trough: wrench-fault related basin on the border of the equatorial Atlantic. In Developments in Geotectonics (Vol. 22, pp. 787-819). Elsevier.

[7] Obaje, N., Wehner, H., Scheeder, G., Abubakar, M., and Jauro, A. (2004). Hydrocarbon prospectivity of Nigeria's inland basins: From the viewpoint of organic geochemistry and organic petrology. AAPG bulletin, 88(3), 325-353.

[8] Reyment, R. A. (1965). Aspects of the geology of Nigeria: The stratigraphy of the Cretaceous and Cenozoic deposits: Ibadan university press.

[9] Akande, S., Horn, E., and Reutel, C. (1988). Minerology, fluid inclusion and genesis of the Arufu and Akwana $\mathrm{Pb} \mathrm{Zn} \mathrm{F}$ mineralization, middle Benue Trough, Nigeria. Journal of African Earth Sciences (and the Middle East), 7(1), 167-180.

[10] Nwachukwu, S. O. (2009). The tectonic evolution of the the southern portion of the Benue Trough, Nigeria. Geological Magazine,

$109(5)$,

411-419.
doi:10.1017/S0016756800039790.

[11] Olade, M. (1975). Evolution of Nigeria's Benue Trough (Aulacogen): a tectonic model. Geological magazine, 112(6), 575-583.

[12] Nwajide, C. (1990). Sedimentation and paleogeography of the Central Benue Trough, Nigeria. The Benue Trough Structure and Evolution, View eg. And Shn, Braunschweig, 19-38.

[13] Zektser, I. S., Belousova, A. P., and Dudov, V. Y. (1995). Regional assessment and mapping of groundwater vulnerability to contamination. Environmental geology, 25(4), 225-231.

[14] Ghafari, S., Hasan, M., and Aroua, M. K. (2008). Bioelectrochemical removal of nitrate from water and wastewater-A review. Bioresource Technology, 99(10), 3965-3974. doi:https://doi.org/10.1016/j.biortech.2007.05.026.

[15] Hasan, Z., Khan, N. A., and Jhung, S. H. (2016). Adsorptive removal of diclofenac sodium from water with Zr-based metal-organic frameworks. Chemical Engineering Journal, 284(Supplement C), 1406-1413. doi:https://doi.org/10.1016/j.cej.2015.08.087.

[16] Zahid, A., Hassan, M. Q., Balke, K.-D., Flegr, M., and Clark, D. W. (2008). Groundwater chemistry and occurrence of arsenic in the Meghna floodplain aquifer, southeastern Bangladesh. Environmental Geology, 54(6), 1247-1260. doi:10.1007/s00254-007-0907-3.

[17] Tijani, M. N. (2004). Evolution of saline waters and brines in the Benue-Trough, Nigeria. Applied Geochemistry, 19(9), 1355-1365.

doi:https://doi.org/10.1016/j.apgeochem.2004.01.020.

[18] Standards Organization of Nigeria. (2007). Nigerian Standard for drinking water quality.

[19] Moore, J. W. (1991). Arsenic. In Inorganic Contaminants of Surface Water (pp. 20-33): Springer.

[20] World Health Organization, W. H. O. (2004). Guidelines for drinking-water quality (Vol. 1): World Health Organization.

[21] World Health Organisation, W. H. O. (2011). Guidelines for drinking-water quality. World Health Organization, 216, 303304.

[22] Chaanda, M. S., Obaje, N. G., Moumouni, A., Goki, N. G., and Lar, U. A. (2010). Environmental Impact of Artisanal Mining of Barites in Azara Area, Middle Benue Trough, Nigeria. OnLine Journal of Earth Sciences ISSN 1991-7708, Vol 4 (1), pp. 38-42.

[23] Lar, U. A., and Sallau, A. K. (2005). Trace element geochistry of the Keana brines field, Middle benue Trough, Nigeria. Environ. Geochem. Heath, 27: 331-339.

[24] Sadashivaiah, C., Ramakrishnaiah, C., \& Ranganna, G. (2008). Hydrochemical Analysis and Evaluation of Groundwater Quality in Tumkur Taluk, Karnataka State, India. International Journal of Environmental Research and Public Health, 5(3), 158.

[25] Vinceti, M., Wei, E. T., Malagoli, C., Bergomi, M., \& Vivoli, G. (2001). Adverse Health Effects of Selenium in Humans. In Reviews on Environmental Health (Vol. 16, pp. 233). 